\title{
Assessing the north Indian maritime cyclonic turbulences with extraordinary reference to incredibly serious cyclonic tempest Fani: Meteorological inconstancy, India's readiness with the awful consequences
}

Soumen Chatterjee

The University of Burdwan

Amab Kundu ( $\square$ arnknd@gmail.com )

Bankura University https://orcid.org/0000-0002-2291-5741

\section{Research Article}

Keywords: Preparedness of Cyclone, Synthetic Aperture Radar, Google Earth Engine, Severe Cyclone (Fani)

Posted Date: June 30th, 2021

DOl: https://doi.org/10.21203/rs.3.rs-574592/v1

License: (c) (i) This work is licensed under a Creative Commons Attribution 4.0 International License. Read Full License 


\section{Abstract}

Having a complete coastline region around $7516 \mathrm{~km}$ with a $5400 \mathrm{~km}$. long territory coastline, India is exceptionally susceptible to common perils like tropical cyclones (TCs). The investigation dependent on the historic datasets (1891-2019) of TCs over the North Indian Ocean (NIO) additionally guarantees that the four seaside states (West Bengal, Odisha, Andhra Pradesh, and Tamil Nadu) and one union territory (Pondicherry/Puducherry) on the east coast much of the time face cyclonic tempest than other seaside parts of India. The periodical pattern (pre-monsoon, monsoon, and post-monsoon) of cyclonic tempests over the Bay of Bengal (BoB) and Arabian Sea (AS) over the past 150 years likewise help to unfurl the way that the West Bengal and Odisha coast are unmasked to TCs generally during the storm season (June to September) including with robust winds, heavy precipitation, and high tempest surge. The extremely severe cyclonic storm (ESCS) Fani is the most extraordinary summer cyclones, the first one in quite a while to strike the seaside part of Odisha on May 3, 2019, and one of the three most exceedingly terrible cyclones over the past 150 years with a supported surface wind speed of 175-180 kph. Odisha has been influenced unpleasantly because of the supremacy of Fani. While the loss of life was restricted within 64 because of the fast evacuation of almost 1.68 million persons, the executioner cyclone has caused excessive destructions to sociable extents (lodging, education, and food security), beneficial areas (cultivation, fisheries, and domesticated animals), and informative zones (power, telecom, street, water offices, and public constructions). The measured costs have arrived at almost 4.18 billion United States Dollar (USD) just in Odisha. The southern portion of West Bengal has additionally been influenced severely because of extraordinary downpours and high tempest surges (2-3 m above mean sea level). In this study, we used remote sensing-based Sentinel-1 Synthetic Aperture Radar (SAR) Ground Range Detected (GRD) Level-1 datasets through Google Earth Engine (GEE) platform for evaluating the fatal cyclone Fani. Hereafter, the current investigation effectively advocates the historic experience of TCs over NIO with specific reference to ESCS Fani including its meteorological instability, readiness, and the path of annihilation.

\section{Introduction}

Tropical cyclones (TCs), perhaps the greatest danger to life and property have caused 0.77 million deaths and 1407.6 billion USD economic loss worldwide in the last fifty years with an average of 43 deaths and 78 million USD harms each day (WMO, 2020). India is not far behind in this regard for having about 5400 $\mathrm{km}$ long mainland coastline out of a total of $7516 \mathrm{~km}$. coastal tract (Mohapatra, 2015; Mohapatra et al., 2012; NCRMP, 2019). So, the country is also highly vulnerable to natural hazards like TCs which are originated in the NIO [the Arabian Sea (AS) and Bay of Bengal (BoB)], although the region produces only $7 \%$ of the world's TC (Dube et al., 1997; Mohapatra, 2015). Out of 96 cyclone-affected districts of India (including 72 coastal districts), 12, 41,30 and 13 districts come under very high, high, moderate, and less cyclone hazard-prone types, respectively (Mohapatra et al., 2012; RSMC, 2018a), based on the frequency of overall cyclones and severe cyclones, actual/estimated extreme wind strength, Probable Maximum Storm Surge (PMSS) and Probable Maximum Precipitation (PMP). Besides, the studies of Dube et al., (1997), Mohapatra (2015), Mohapatra et al., (2012), and RSMC (2018) also claim that almost all the seaside districts of West Bengal, Odisha, Andhra Pradesh, and Tamil Nadu come under high to very high cyclone hazard-prone type because the majority of cyclones arise in BoB as compared to the AS. On the other hand, almost the entire eastern coastal tract of India has been identified as a very high damage risk zone in terms of wind hazard vulnerability of India by the Building Materials \& Technology Promotion Council (BMTPC, 2019) under the Ministry of Housing and Urban Affairs, Govt. of India.

The year, 2019 has experienced four more intense cyclonic storms, but the ESCS Fani is the only tropical cyclone of the year that has made landfall a very severe cyclonic storm in the coastal part of Odisha (Puri district) on 3rd May (RSMC, 2020). It is also the strongest TC to strike Odisha coast since the 1999 super cyclone not only in terms of intensity but also from the perspective of damage in social segments (lodging, education, and food security), productive sectors (farming, fisheries, and livestock) and also informative subdivisions (power, telecom, street, water amenities, and public constructions). Despite taking several pre-storm emergency preparedness plans, ESCS Fani has succeeded to cause large damage of an estimated cost of 4.18 billion USD only within Odisha (India) with 64 human casualty (OSDMA, UN India, WB and ADB, 2019; UNICEF, 2019). So, the present study has focused on the detailed scenario of cyclonic storm distribution over the NIO and trend analysis from 1891 to 2018 with particular reference to Fani and its devastating impact on lives, property, and economy due to high-speed winds, excessive rainfall, storm surge, and flooding.

\section{Historical Background Of Cyclonic Disturbances}

The states like West Bengal, Odisha and Andhra Pradesh situated along the eastern coast of India have experienced severe damages due to TCs originated in the BoB (Chittibabu et al., 2004; Dube et al., 1997; Dube et al., 2000a, 2000b; Mohapatra, 2015; Mohapatra et al., 2012; Rao et al., 2006) because the most of the cyclonic storms tend to arise in the BoB basin as likened to the AS basin with an approximate ratio of 3:1. Naturally, the prepared gridded image based on the genesis of cyclonic storms data over NIO basin by the India Meteorological Department (IMD) indicates that the BoB has experienced a very high frequency of cyclonic storms cumulatively since 1891(Fig. 1a). On the other hand, the inter-annual average values of the past 128 years (1891-2019) also specify that the BoB experiences almost 2 severe or more intense cyclonic storms out of every 6 TCs, whereas the AS originates almost 1 severe or more intense cyclonic storms out of every 2 TCs. So, the above discussion helps to understand the reason behind belonging the coastal tract of northern BoB to the very highly vulnerable cyclone hazard-prone zone with having potentiality to generate high storm surge and killer strong gusty winds. The further analysis also explains that most of the TCs in the lower latitudes in association with the Inter-tropical Convergence Zone (ITCZ) occur during pre-monsoon (March-May) and post-monsoon (October - December) seasons, but the coastal states along with the northern BoB and AS have faced most the cyclonic storms during monsoon period (June - September) (Fig. 1b). Thus, the high-intensity devastating summer cyclone is the rarest event in the long cyclonic history of northern BoB.

Extensive work has been also done by Mooley (1980), Singh et al., (2000, 2001), Singh (2007), Srivastava et al., (2000), and Mohapatra et al., (2017) for determining the change analysis in the intensity and frequency distribution of TCs over BoB and AS. In the current study, the temporal frequency distribution data (1891-2019) of cyclonic disturbances by IMD (RSMC, 2019) has been analyzed for obtaining a long-term trend of TCs over NIO. The analysis also helps to unfold the fact that the 30 years moving average lines of overall cyclonic storms and severe or more intense TCs almost follow the constructed regression 
lines for the period of 1891 to 2019 (Fig. 2a). To analyze the historical trend of TCs in more detail, the intensification rate of cyclonic storms to severe or more intense cyclonic storms has been examined over BoB and AS for the past 128 years. The results help to understand that the changes in the strengthening degree of cyclonic storms to severe or more intense TCs have increased over time in the case of both the BoB and $A S$ with the $R^{2}$ values of 0.0985 and 0.0054 , respectively (Figs. $2 \mathrm{~b}$ and $2 \mathrm{c}$ ).

The coastal districts of Odisha have experienced several cyclonic storms with strong winds, floodings, and very high storm surges, but Fani is the rarest summertime cyclone, the first in 43 years, and one of the three worst cyclones in the last 150 years to hit the seaside part of Odisha with immense economic and social impact (OSDMA, UN India, WB and ADB, 2019; UNICEF, 2019). Then it further proceeds towards West Bengal and finally weakens over Bangladesh and its adjoining Indian territory (central Assam).

\section{Materials And Methods}

Large numerical datasets, pre-storm, and post-storm images, and extensive study are required for analyzing the historical background of TCs over NIO, the meteorological overview of ESCS Fani (wind speed data, atmospheric pressure data, rainfall details, and storm surge information), and damage details including inundation statistics with causality due to the devastation caused by the cyclone Fani. The data relating to the frequencies of TCs over the BoB and the AS for the period of 1891 to 2019 have been obtained from the website of RSMC (2019) for tropical cyclones over NIO in association with IMD. Two types of images have been used for the analysis and visualization of the different aspects of the ESCS Fani. SAR images of Sentinel-1 (pre-storm and post-storm) have been examined in GEE environment, a cloud-based platform for planetary-scale eco-friendly data analysis (Gorelick et al., 2017) for inland and coastal inundation mapping due to heavy rainfall and storm surges during Fani by dividing the entire affected area of West Bengal and Odisha into two windows (Fig. 3, Table 1). The first window includes the southern districts of West Bengal and its surroundings. On the other hand, the second window includes the eastern portion of Odisha and its surroundings. The flooded areas have been mapped by using certain codes in GEE. For further analysis, the reliability of extracted flooded areas has been measured by collecting 80 samples for each classification unit (viz., water bodies, flooded lands, and non-flooded lands) from both windows which have been referred to as the region of interest (ROI) in Fig. 3. The accuracy assessment table indicates that the computed overall accuracy values are very high in the case of VV and VH polarization for both windows (Table 2). Besides, GPM IMERG Final Precipitation (0.1 degree X 0.1 degree, V06) data (Huffman, 2019) have also been used for the analysis of daily rainfall intensity during the storm event in the Giovanni environment. The track-related information and other meteorological details regarding cyclonic storm Fani have been collected from the archive section of the RSMC for Tropical Cyclones over NIO website (http://www.rsmcnewdelhi.imd.gov.in/index.php?lang=en) as in the form of 'Best Tracks Data' and 'Bulletins', respectively. The storm surge height information along the coastal tract of Odisha and West Bengal has also been collected from the Emergency Response Coordination Centre (ERCC, 2019) portal in association with the Joint Research Centre (JRC) under Hurricane Weather Research and Forecasting (HWRF) of National Oceanic and Atmospheric Administration (NOAA).

Table 1 Dataset used for the analysis and visualization different aspects of very severe cyclone Fani

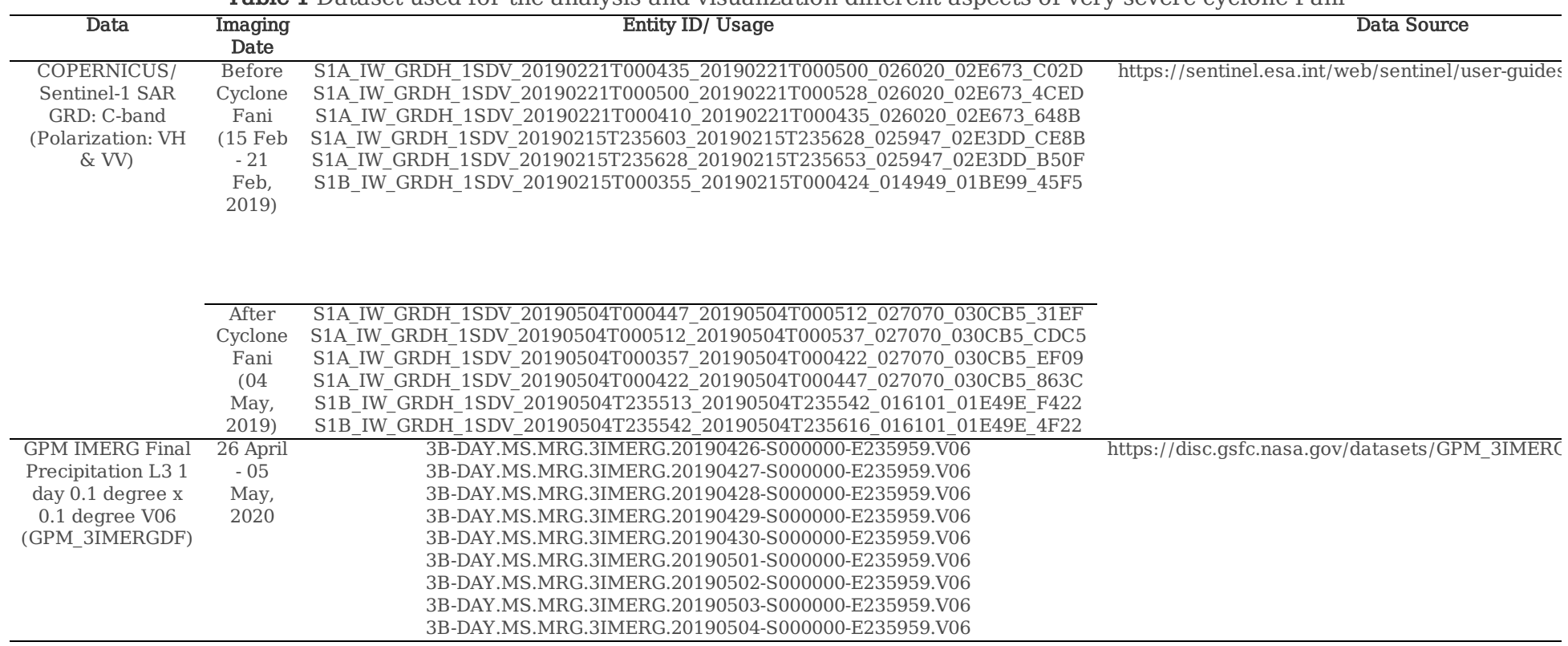


Table 2

Accuracy assessment table for measuring the precision of extracted flooded area from Sentinel-1 SAR images during ESCS Fani

\begin{tabular}{|c|c|c|c|c|c|c|c|c|c|c|c|c|}
\hline \multirow{4}{*}{$\begin{array}{l}\text { Classification } \\
\text { Data }\end{array}$} & \multicolumn{12}{|c|}{ Accuracy assessment value (\%) } \\
\hline & \multicolumn{6}{|c|}{ Odisha and surroundings (Window 2) } & \multicolumn{6}{|c|}{ West Bengal and surroundings (Window 1 ) } \\
\hline & \multicolumn{3}{|c|}{ VH polarization } & \multicolumn{3}{|c|}{$\mathrm{W}$ polarization } & \multicolumn{3}{|c|}{ VH polarization } & \multicolumn{3}{|c|}{ W polarization } \\
\hline & $\begin{array}{l}\text { Producer's } \\
\text { Accuracy }\end{array}$ & $\begin{array}{l}\text { User's } \\
\text { Accuracy }\end{array}$ & Overall & $\begin{array}{l}\text { Producer's } \\
\text { Accuracy }\end{array}$ & $\begin{array}{l}\text { User's } \\
\text { Accuracy }\end{array}$ & Overall & $\begin{array}{l}\text { Producer's } \\
\text { Accuracy }\end{array}$ & $\begin{array}{l}\text { User's } \\
\text { Accuracy }\end{array}$ & Overall & $\begin{array}{l}\text { Producer's } \\
\text { Accuracy }\end{array}$ & $\begin{array}{l}\text { User's } \\
\text { Accuracy }\end{array}$ & Ov \\
\hline Water bodies & 100 & 100 & \multirow[t]{3}{*}{92.92} & 100 & 100 & \multirow[t]{3}{*}{92.50} & 100 & 100 & \multirow[t]{3}{*}{95.42} & 100 & 100 & \multirow[t]{3}{*}{93} \\
\hline $\begin{array}{l}\text { Flooded } \\
\text { lands }\end{array}$ & 88.88 & 90 & & 89.74 & 87.50 & & 100 & 86.25 & & 98.51 & 82.50 & \\
\hline $\begin{array}{l}\text { Non-flooded } \\
\text { lands }\end{array}$ & 89.87 & 88.75 & & 87.80 & 90 & & 88.89 & 100 & & 84.95 & 98.75 & \\
\hline
\end{tabular}

Very few research works have been done by Acharyya et al., (2020), Kumar et al., (2020), Liu and Zhu (2020), and Mohanty et al., (2020a, b) on different aspects of cyclonic storms Fani. Several reports have also been published based on the impact assessment of ESCS Fani by different reliable sources like UNICEF (2019), OSDMA, UN, WB and ADB (2019), IRC (2019), and Humanity Road (2019). The summary of the research articles and published reports have been enlisted in Table 3. Based on the available information, it can be claimed that the present study has its significance in terms of subject matter because no discussion has been made so far in any study where the coastal and inland flooded zones have been delineated with the calculation of inundation statistics due to heavy rainfall and storm surge during cyclone Fani. Besides, this is the only article where India's preparedness and damage statistics have also been discussed briefly in the context of cyclonic storm Fani with the long historical background of TCs over the NIO.

Table 3 Evaluation of research articles and reports on extremely severe cyclonic storm (ESCS) Fani

\begin{tabular}{|c|c|c|c|c|c|c|c|c|c|c|c|}
\hline \multirow[b]{2}{*}{ Type } & \multirow[b]{2}{*}{ Entity } & \multicolumn{10}{|c|}{ Focused areas of the study } \\
\hline & & 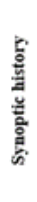 & 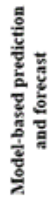 & 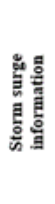 & 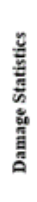 & 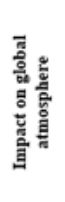 & 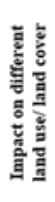 & 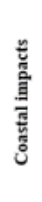 & 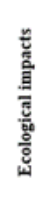 & 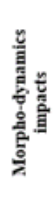 & 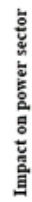 \\
\hline 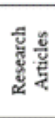 & $\begin{array}{l}\text { Acharyya et al. (2020) } \\
\text { Kumar et al. (2020) } \\
\text { Liu and Zhu (2020) } \\
\text { Mohanty et al. (2020a) } \\
\text { Mohanty et al. (2020b) }\end{array}$ & $\checkmark$ & $\checkmark$ & & $\checkmark$ & $\checkmark$ & $\checkmark$ & 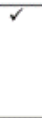 & $\checkmark$ & $\checkmark$ & $\checkmark$ \\
\hline 总 & $\begin{array}{l}\text { Humanity Road (2019) } \\
\text { IRC (2019) } \\
\text { OSDMA, UN, WB \& ADB } \\
\text { (2019) } \\
\text { UNICEF (2019) }\end{array}$ & & & $\begin{array}{l}\checkmark \\
\checkmark \\
r\end{array}$ & $\begin{array}{l}\checkmark \\
\checkmark \\
\checkmark \\
\checkmark\end{array}$ & & $\checkmark$ & $\checkmark$ & $\checkmark$ & & $\checkmark$ \\
\hline
\end{tabular}

\section{Synoptic History Of Escs Fani}

The cyclonic storm Fani has covered a long distance (nearly 3090 km) combined over the Bay of Bengal, Indian, and Bangladesh landmass (Fig. 4). It has spawned as a depression (D) over the eastern equatorial Indian Ocean and adjoining southeast BoB on April 26, 2019. Then it has moved northwestwards with a speed of about $56 \mathrm{kph}$ and has intensified into a deep depression (DD) over south-eastern BoB on April 27. It has again moved north-northwestwards and has intensified into the cyclonic storm (CS) at 11:30 hrs IST on the same date near latitude $5.2^{\circ} \mathrm{N}$ and longitude $88.6^{\circ} \mathrm{E}$. After intensifying into CS, it has again moved northwestwards and has laid centered near latitude $5.4^{\circ} \mathrm{N}$ and longitude $88.5^{\circ} \mathrm{E}$ at $14: 30 \mathrm{hrs}$ IST. At about 17:30 hrs IST on that very day, it has curved towards the north. After gaining more speed, Fani has further strengthened into a severe cyclonic storm (SCS) near $10.1^{\circ} \mathrm{N}$ latitude and $86.7^{\circ} \mathrm{E}$ longitude over the central portion of the northern BoB at 17:30 hrs IST on April 29. This rarest summer cyclone has transformed into a very severe cyclonic storm (VSCS) at 05:30 hrs IST on the very next day. After moving northwestwards, it has further strengthened into an ESCS on April 30 at 17:30 hrs IST. Although the cyclonic storm Fani has continued its journey as ESCS till 08:30 hrs IST of May 3, it has geared up its speed initially up to almost 213 kph with gusting to $210 \mathrm{kph}$ till May 2 (at about 20:30 hrs IST) and has weakened a little bit on the very next day. The ESCS Fani has made landfall near Puri (Odisha Coast) as VSCS with an extreme continued wind speed of nearly $157 \mathrm{kph}$ with gusting to $205 \mathrm{kph}$ between 08:00 to 10:00 hrs IST on May 3, 2019. After crossing the Odisha coast, it has further continued to travel north-northeastwards and has debilitated gradually after emerging into Gangetic West Bengal as an SCS with a wind speed of $111 \mathrm{Kmph}$ with gusting to $115 \mathrm{Kmph}$ by the early morning of May 4 . The remnants of SCS Fani have moved towards eastnortheastwards and have weakened into a DD over Bangladesh. Finally, it has transformed into a well-marked low pressure over central Assam and neighborhood at 23:30 hrs IST on May 4, 2019. The best track details of ESCS Fani have been presented in Table 4. 
Table 4

Best track details for very severe cyclonic storm Fani, 26 April - 4 May 2019

\begin{tabular}{|c|c|c|c|c|c|c|c|c|}
\hline \multicolumn{2}{|l|}{ Date/Time } & \multirow[t]{2}{*}{$\begin{array}{l}\text { Lat. } \\
\left({ }^{\circ} \mathrm{N}\right)\end{array}$} & \multirow[t]{2}{*}{$\begin{array}{l}\text { Long. } \\
\left({ }^{\circ} \mathrm{E}\right)\end{array}$} & \multirow[t]{2}{*}{$\begin{array}{l}\text { Estimated Central } \\
\text { Pressure }(\mathrm{hPa})\end{array}$} & \multicolumn{2}{|c|}{$\begin{array}{l}\text { Average Wind } \\
\text { Speed }\end{array}$} & \multirow[t]{2}{*}{ Status } & \multirow[t]{2}{*}{ Remarks } \\
\hline UTC & IST & & & & kt. & km. & & \\
\hline 26/06:00 & 26/11:30 & 3 & 89.4 & 998 & 25 & 46.25 & D & \multirow[t]{7}{*}{ Over South-east Bay of Bengal (SE BoB) } \\
\hline 27/00:00 & $27 / 05: 30$ & 4.5 & 88.8 & 997 & 30 & 55.50 & DD & \\
\hline 27/03:00 & 27/08:30 & 4.9 & 88.7 & 996 & 30 & 55.50 & DD & \\
\hline 27/06:00 & 27/11:30 & 5.2 & 88.6 & 995 & 35 & 64.75 & cs & \\
\hline 27/09:00 & 27/14:30 & 5.4 & 88.5 & 994 & 40 & 74.00 & CS & \\
\hline 27/12:00 & $27 / 17: 30$ & 5.9 & 88.5 & 992 & 45 & 83.25 & cs & \\
\hline 28/12:00 & 28/17:30 & 8.2 & 87 & 992 & 45 & 83.25 & CS & \\
\hline 29/12:00 & 29/17:30 & 10.1 & 86.7 & 986 & 55 & 101.75 & scs & \multirow[t]{2}{*}{ Over Central Southem Bay of Bengal (CS BoB) } \\
\hline 29/21:00 & $30 / 02: 30$ & 11.1 & 86.5 & 982 & 65 & 120.25 & Vscs & \\
\hline 30/00:00 & $30 / 05: 30$ & 11.7 & 86.5 & 980 & 70 & 129.50 & vscs & \multirow[t]{5}{*}{ Over South-west Bay of Bengal (SW BoB) } \\
\hline 30/03:00 & $30 / 08: 30$ & 12.3 & 86.2 & 974 & 75 & 138.75 & vscs & \\
\hline 30/06:00 & $30 / 11: 30$ & 12.6 & 85.7 & 970 & 80 & 148.00 & vscs & \\
\hline 30/09:00 & $30 / 14: 30$ & 13 & 85.3 & 966 & 85 & 157.25 & vscs & \\
\hline $30 / 12: 00$ & $30 / 17: 30$ & 13.3 & 84.7 & 962 & 90 & 166.50 & ESCS & \\
\hline 30/15:00 & $30 / 20: 30$ & 13.4 & 84.5 & 957 & 95 & 175.75 & ESCS & \multirow[t]{6}{*}{ Over West-central Bay of Bengal (WC BoB) } \\
\hline 01/09:00 & 01/14:30 & 14.5 & 84.1 & 955 & 95 & 175.75 & ESCS & \\
\hline 01/12:00 & 01/17:30 & 14.9 & 84.1 & 950 & 100 & 185.00 & ESCS & \\
\hline 02/00:00 & 02/05:30 & 15.9 & 84.5 & 945 & 105 & 194.25 & ESCS & \\
\hline 02/06:00 & 02/11:30 & 16.7 & 84.8 & 940 & 110 & 203.50 & ESCS & \\
\hline 02/09:00 & 02/14:30 & 17.1 & 84.8 & 932 & 115 & 212.75 & ESCS & \\
\hline 02/15:00 & $02 / 20: 30$ & 17.8 & 84.9 & 934 & 115 & 212.75 & ESCS & \multirow[t]{2}{*}{ Over North-west Bay of Bengal (NW BoB) } \\
\hline 03/03:00 & 03/08:30 & 19.6 & 85.7 & 952 & 100 & 185.00 & ESCS & \\
\hline 03/06:00 & 03/11:30 & 20.2 & 85.9 & 966 & 85 & 157.25 & vscs & \multirow{7}{*}{$\begin{array}{l}\text { Crossed Odisha coast close to Puri (near lat. } 19.75 \mathrm{~N} \text { and } \\
\text { Long. 85.70E) between } 0230 \text { to } 0430 \text { UTC on } 3 \text { May } 2019 \\
\text { (Over Odisha \& West Bengal) }\end{array}$} \\
\hline 03/09:00 & 03/14:30 & 20.6 & 86 & 970 & 75 & 138.75 & vscs & \\
\hline 03/12:00 & 03/17:30 & 21.1 & 86.5 & 976 & 70 & 129.50 & VSCS & \\
\hline 03/15:00 & 03/20:30 & 21.5 & 86.7 & 980 & 60 & 111.00 & scs & \\
\hline 03/18:00 & 03/23:30 & 21.9 & 87.1 & 984 & 55 & 101.75 & scs & \\
\hline 03/21:00 & $04 / 02: 30$ & 22.5 & 87.9 & 986 & 50 & 92.50 & scs & \\
\hline 04/00:00 & 04/05:30 & 23.1 & 88.2 & 994 & 40 & 74.00 & cs & \\
\hline 04/03:00 & 04/08:30 & 23.6 & 88.8 & 996 & 30 & 55.50 & DD & \multirow[t]{2}{*}{ Over Bangladesh } \\
\hline 04/06:00 & 04/11:30 & 24.3 & 89.3 & 998 & 25 & 46.25 & D & \\
\hline 04/12:00 & 04/17:30 & 25.2 & 90.7 & 1000 & 20 & 37.00 & $\mathrm{D}$ & Over central Assam \& neighbourhood \\
\hline
\end{tabular}

The meteorological observations include the sustained wind speed and also the atmospheric pressure during the storm event (Fig. 5). Fani's maximum wind speed of nearly $213 \mathrm{kph}$ has occurred over NW BoB just fifteen hours before making landfall on the Odisha coast at 20:30 hrs IST on May 2. The minimum pressure of cyclonic storm Fani has been estimated to be $932 \mathrm{hPa}$ on that particular day. Conversely, the maximum wind speed has been observed nearly 157 kph with $966 \mathrm{hPa}$ atmospheric pressure (the lowest estimated central pressure after making landfall) at the time of striking Puri, one of the coastal districts Odisha at 11:30 hrs IST on May 3. The correlation coefficient value $(r)$ is indicating the strong negative relationship $(-0.98)$ between two weather variables (wind speed and atmospheric pressure) which are collected along the best track of summer cyclonic storm Fani. 


\section{Results And Discussion}

This particular section of the study includes three main aspects which are intimately related to cyclonic storm Fani, viz., India's preparedness, inundation details, and other damage statistics. The first one (disaster preparedness) helps to understand how India has able to tackle and overcome the situation by taking management proper steps and keeping the death toll in control. The last two aspects (inundation details with other damage statistics) help to get the idea about the devastation caused by ESCS Fani, despite taking the necessary steps to handle the cyclone situation.

\subsection{India's preparedness}

The pre-storm and post-storm disaster preparedness programs always create several challenging situations for the country like India, the world's second-most populous land with 1366 million residents (United Nations, 2019). In the case of the tropical cyclone, the seaside districts of India have to face more dangerous situations for having a high population density. Nearly $40 \%$ of the total population is more or less exposed to cyclones owing to living within 100 $\mathrm{km}$ of shoreline in India (NCRMP, 2019). The robust winds with heavy rainfall and storm surge during cyclonic storms can cause a severe loss that includes complete or partial destruction of families, buildings, roads, power networks, and water outages (FEMA, 2017). So, the proper pre-storm emergency preparedness plan takes an important role to reduce the damages and casualties caused by an unavoidable disaster like the tropical cyclone.

The National Disaster Response Force (NDRF), Odisha State Disaster Management Authority (OSDMA), West Bengal Disaster Management and Civil Defence Department (WBDM and CD), Andhra Pradesh State Disaster Management Authority (APSDMA), Indian Red Cross Society, and United Nations (UN) have worked jointly for ensuring safety to the common people who are living along the track of ESCS Fani. Nearly 1.68 million persons have been evacuated from the path of Fani of three affected states (Odisha, West Bengal, and Andhra Pradesh) of India (UNICEF, 2019). This is considered the largest evacuation process not only in the cyclonic history of India but also in the cyclonic history of the World. A large number of cyclone or flood relief camps (9000 in Odisha, 471 in West Bengal, and 120 in Andhra Pradesh) have been used temporarily for the relocation of evacuated people during the storm event. More than 45000 volunteers, 2000 emergency workers, 100000 officials have worked day and night in the rescue operation in Odisha to fight against this deadly tropical cyclone. A combined amount of nearly 153 million USD has been released in advance from State Disaster Response Fund (SDRF) to State Governments of Odisha, West Bengal, and Andhra Pradesh. As Fani has made landfall near Puri of Odisha Coast, special attention has been paid to the health sector as pre and post-storm measures by the Odisha government (IRC, 2019). After the storm event, 302 affected public health centers have been restored for providing emergency treatment. 184 mobile medical teams have been deployed for minor injured persons. 1945 pregnant women have also been shifted to delivery points. Besides, several other measures have also been occupied by the national, state, and local governments to battle against this monstrous ESCS. IMD received appreciation from the World Meteorological Organization (WMO) and other national \& international scientific community and media for pinpoint accuracy during the storm event. The United Nations Office for Disaster Risk Reduction (UNDRR) has also praised India's zero casualty approach to manage extreme weather events like Fani.

\subsection{Inundation detail}

Effective monitoring of floods is quite impossible without the use of satellite images. GEE has made the work easier than before because of its capabilities to detect temporal changes on the earth's surface (Uddin et al., 2019; DeVries et al., 2020; Agnihotri et al., 2019; Clement et al., 2017; Kussul et al., 2011) using the Sentinel-1's C-band SAR active sensor derived images, an independent dataset of any time of the day or night, irrespective of weather and environmental situations (ESA, 2020). So this particular cloud-based platform has been used for monitoring flood situation due to heavy rainfall (responsible for inland flooding) and storm surge (caused coastal inundation) during ESCS Fani.

The rainfall associated with ESCS Fani based on daily accumulated precipitation extracted from GPM IMERG final precipitation (0.1 degree X 0.1 degree, V06) data in Giovanni environment has been represented in Fig. 6 from April 26 to May 4, 2019. It indicates the occurrence of heavy to very heavy downpour over coastal Odisha, Gangetic West Bengal, and adjoining Bangladesh on May 3. Most of the places have experienced more than 75 mm accumulated rainfall in $24 \mathrm{hrs}$ on that very day. As the cyclonic storm Fani has moved towards northeastern India through Bangladesh along the track and has weakened into a depression on May 4, it has also caused a large amount of rainfall over Bangladesh and adjoining areas of northeastern states of India (Assam, Meghalaya, and Arunachal Pradesh). On the other hand, the storm surge information from the Emergency Response Coordination Centre (ERCC) portal in association with JRC under NOAA/HWRF also depicts that the part of Purba Medinipur and South 24 Parganas district of West Bengal have experienced high-level storm surge, varying in height from 2 to 3 meters during the storm event (Fig. 7). The coastal tract of Puri, Baleshwar \& the part of Bhadrak district (Odisha) has faced moderate level storm surge (1-2 meters high) with the coastal part of Purba Medinipur and South 24 Parganas (West Bengal). The rest of the South 24 Parganas district from the seaside tract of West Bengal, Jagatsinghapur, and Kendrapara districts from the coastal tract of Odisha have also experienced lowlevel storm surge during cyclonic storm Fani. Thus, the heavy rainfall and powerful storm surge have jointly caused major damages due to inundation in the coastal districts of Odisha and West Bengal.

The cyclone-affected regions of Odisha and West Bengal have been divided into five equal width zones (15 km. each) based on the distance from the coast for a more detailed explanation, but it doesn't signify that any inundation has not occurred beyond that extent (Fig. 7). The results derived from the investigation of the SAR images in the GEE environment help to understand the overall flood scenario over the major affected regions because of heavy rainfall and powerful storm surge (Table 5). The computed inundation statistics claim that Puri, one of the coastal districts of Odisha has faced major flooding due to a large amount of rainfall with a high level of storm surge during the storm event. Besides, the other parts of the first zone ( $0-15 \mathrm{~km})$ within Odisha have also experienced large inundation than other zones due to the heavy downpour and moderate to low-level storm surge because the advancement of ESCS Fani has occurred towards the Gangetic West Bengal almost along the coastal tract of Odisha. On the other hand, the coastal tract of West Bengal has faced a significant inundation for experiencing high to low-level storm surge with heavy rainfall. The statistics also claim that the highest amount of inundation has occurred in the fourth zone $(45-60 \mathrm{~km})$ of West Bengal than other parts of the cyclone-affected regions because the summer cyclone Fani has 
moved towards Bangladesh through this zone and has caused heavy rainstorm on May 3, 2019. Figure 8 helps to get a better view of the most affected regions due to inundation during cyclonic storm Fani over Odisha and West Bengal.

Table 5

Inundation statistics of Odisha and West Bengal during extremely severe cyclonic storm (ESCS) Fani

\begin{tabular}{|lll|}
\hline Distance from coast (km) & \multicolumn{2}{l|}{ Inundated Area (Sq. km.) } \\
\cline { 2 - 3 } & Odisha & West Bengal \\
\hline $0-15$ & 47.99 & 50.41 \\
\hline $15-30$ & 20.03 & 19.22 \\
\hline $30-45$ & 18.05 & 39.49 \\
\hline $45-60$ & 20.67 & 63.51 \\
\hline $60-75$ & 23.07 & 30.67 \\
\hline
\end{tabular}

\subsection{Other damage statistics}

If the flooding has been explained as the only consequence of the devastating tropical cyclone, the severity of the storm will be underestimated. The intensive rainfall, strong winds, and storm surges cause several other damages during storm event across the world, making the coastal people vulnerable to a cyclone (Khalil, 1993; Wang and Xu, 2008; Li and Li, 2013; Ward et al., 2011; Done et al., 2018; Mori and Takemi, 2016). The deadly cyclonic storm Fani has also unleashed copious rainfall with the powerful windstorm that has gusted up to $205 \mathrm{kph}$, leading to fatalities, destruction of kutcha houses, partial damage to buildings and other properties like roads, power sectors, health care centers, educational sector, embankment, etc. The trail of devastation caused by ESCS Fani in the large part of Odisha with West Bengal and Andhra Pradesh has been explained briefly in Table 6 .

Table 6 Damage caused by the very severe cyclonic storm Fani in Odisha, West Bengal and Andhra Pradesh of India

(Source: UNICEF, 2019; Odisha State Disaster Management Authority, United Nations, World Bank and ADB 2019) 


\begin{tabular}{|c|c|c|c|}
\hline \multirow[t]{5}{*}{ Total Damage across Odisha, West Bengal and Andhra Pradesh } & \multicolumn{2}{|c|}{ People affected (million) } & 28 \\
\hline & \multicolumn{2}{|l|}{ Districts affected } & 24 \\
\hline & \multicolumn{2}{|c|}{ Deaths reported (all from Odisha) } & 64 \\
\hline & \multicolumn{2}{|l|}{ Building affected } & 4610 \\
\hline & \multicolumn{2}{|c|}{ Livestock Casualty (million) } & 3.73 \\
\hline \multirow[t]{22}{*}{ Affected or Damage in Odisha } & \multicolumn{2}{|c|}{ People affected (million) } & 16.5 \\
\hline & \multicolumn{2}{|l|}{ Districts affected } & 14 \\
\hline & \multicolumn{2}{|l|}{ Villages affected } & 18,388 \\
\hline & \multicolumn{2}{|l|}{ Deaths reported } & 64 \\
\hline & \multicolumn{2}{|c|}{ Perennial crops damage (sq. km) } & 197 \\
\hline & \multicolumn{2}{|c|}{ Total estimated costs in USD (billion) } & 4.18 \\
\hline & \multicolumn{2}{|c|}{ Casualties of poultry birds (million) } & 5.4 \\
\hline & \multirow[t]{3}{*}{ Fisheries } & Traditional fishermen (million) & 0.15 \\
\hline & & Traditional marine fishing boats & 6,416 \\
\hline & & Fishing ponds & 2,524 \\
\hline & \multirow[t]{3}{*}{ Educational sector } & Primary and Secondary schools & 5,735 \\
\hline & & Colleges (Govt. \& Govt. aided) & 102 \\
\hline & & Universities & 5 \\
\hline & \multirow[t]{2}{*}{ Health sector } & Public Health Facilities & 1,031 \\
\hline & & Anganwadi centres & 2,513 \\
\hline & \multirow[t]{2}{*}{ Houses damaged } & Rural & 295,703 \\
\hline & & Urban & 66,040 \\
\hline & \multirow[t]{2}{*}{ Power sector } & High tension poles & 200 \\
\hline & & Distribution transformers & 11,077 \\
\hline & \multicolumn{2}{|c|}{ Length of damaged embankments (km) } & 22.67 \\
\hline & \multicolumn{2}{|c|}{ Length of damaged roads (km) } & 11,763 \\
\hline & \multicolumn{2}{|c|}{ Trees damaged (million) } & 2.19 \\
\hline
\end{tabular}

\section{Conclusion}

The present study has focused on the historical background (1891-2019) of TCs over NIO with specific orientation to ESCS Fani with meteorological inconsistency, India's preparedness, and awful aftermath. The discussion helps to understand that the probabilities of intensification of a cyclonic storm into a severe or more intense cyclone over the northern BoB and AS is maximum during the monsoon period (June to September), differs from the intensification period of the cyclones that originate over the southern BoB and AS mainly during pre-monsoon (March to May) and post-monsoon (October to December) seasons. The recent work similarly confirms that the Utkal (Odisha), Bengal, and Andhra coast receive a higher frequency of TC than any other coastal tracts of India. Fani, one of the three worst cyclonic storms in the last 150 years during pre-monsoon season has made landfall near Puri of Odisha coast and causes devastation over the extensive parts of mainly Odisha and West Bengal, in spite of taking zero casualty approach by the local and national government. Generally, there are two possible ways of obtaining complete resilience against such intense TCs, namely, the pre-storm preparedness plans understanding the risk based on early warning and also resilient infrastructure. India has already able to achieve its first goal. IMD has made the work easier for the Indian Government. But it is quite impossible to manage the second goal, resilient infrastructure for every citizen in a highly populous country like India. For that reason, the government has to build sufficient cyclone and flood shelters so that evacuated people get protection during the storm event and the death toll can be reduced. The several state-level housing schemes and national housing schemes like Indira Awas Yojana (IAY) and Pradhan Mantri Awas Yojana (PMAY) for the economically weaker section can also cause the advancement towards a long-term solution to ensure full resilience against cyclonic storms slowly. So India can't get off immediately from the massive economic losses caused by TCs almost every year until the nation becomes successful to achieve the final goal with time.

\section{Declarations}

\section{Acknowledgments}


This study is largely benefited from the IMD, Regional Specialized Meteorological Centre (RSMC), Building Materials \& Technology Promotion Council (BMTPC), Odisha State Disaster Management Authority (OSDMA), World Bank (WB), Asian Development Bank (ADB), National Aeronautics and Space Administration (NASA), European Space Agency (ESA), United Nations (UN) and Emergency Response Coordination Centre (ERCC). The author wants to acknowledge Giovanni for allowing us to visualize daily rainfall distribution during the storm event and Google Earth Engine (GEE) for providing the opportunity to analyze and visualize the flooded areas.

Funding: This research did not receive any grant.

Data availability: Not applicable.

Code availability: Not applicable.

\section{Ethics Declarations:}

Conflicts of interest: The authors declare that they have no conflict of interest.

\section{References}

1. Acharyya T, Mishra M, Kar D (2020) Rapid impact assessment of extremely severe cyclonic storm Fani on morpho-dynamics \& ecology of Chilika Lake. Odisha India J Coast Conserv 24:37. https://doi.org/10.1007/s11852-020-00754-8

2. Agnihotri AK, Ohri A, Gaur S, Shivam, Das N, Mishra S (2019) Flood inundation mapping and monitoring using SAR data and its impact on Ramganga River in Ganga basin. Environ Monit Assess 191:760. https://doi.org/10.1007/s10661-019-7903-4

3. Building Materials \& Technology Promotion Council (BMTPC): Vulnerability Atlas of India (3rd Edition), Ministry of Housing \& Urban Affairs, Govt. of India, https://bmtpc.org/DataFiles/CMS/file/VAl2019/Index.html, 2019

4. Chittibabu P, Dube SK, Macnabb JB, Murty TS, Rao AD, Mohanty UC, Sinha PC (2004) Mitigation of Flooding and Cyclone Hazard in Orissa, India. Nat Hazards 31:455-485. https://doi.org/10.1023/B:NHAZ.0000023362.26409.22

5. Clement MA, Kilsby CG, Moore P (2017) Multi-temporal synthetic aperture radar flood mapping using change detection. J Flood Risk Manage 11:2:152168. https://doi.org/10.1111/jfr3.12303

6. DeVries B, Huang C, Armston J, Huang W, Jones JW, Lang MW: Rapid and robust monitoring of flood events using Sentinel-1 and Landsat data on the Google Earth Engine, Remote Sens Environ, 240, 111664, https://doi.org/10.1016/j.rse.2020.111664, 2020

7. Done JM, PaiMazumder D, Towler E, Kishtawal CM (2018) Estimating impacts of North Atlantic tropical cyclones using an index of damage potential. Clim Change 146:561-573. https://doi.org/10.1007/s10584-015-1513-0

8. Dube S, Rao A, Sinha P, Murty T, Bahulayan N (1997) Storm surge in the Bay of Bengal and Arabian Sea The problem and its prediction. Mausam 48:283304

9. Dube SK, Chittibabu P, Rao AD, Sinha PC, Murty TS (2000a) Sea levels and coastal inundation due to tropical cyclones in Indian coastal regions of Andhra and Orissa. Mar Geod 23:65-74. https://doi.org/10.1080/01490410050030643

10. Dube SK, Chittibabu P, Rao AD, Sinha PC, Murty TS (2000b) Extreme sea levels associated with severe tropical cyclones hitting Orissa coast of India. Mar Geod 23:75-90. https://doi.org/10.1080/01490410050030652

11. Emergency Response Coordination Centre (ERCC): Tropical Cyclone FANI, DG ECHO Daily Map, Rue de la Loi, 86 B-1040, Brussels/Belgium, Map Id 2909, Gdacs Id 1000561, 2019

12. European Space Agency (ESA), Sentinel-1 SAR User Guide: https://sentinel.esa.int/web/sentinel/user-guides/sentinel-1-sar, 2020, last access: 22 August 2020

13. FEMA: How to Prepare for a Hurricane, United States, 2 pp., 2017

14. Gorelick N, Hancher M, Dixon M, llyushchenko S, Thau D, Moore R (2017) Google Earth Engine: Planetary-scale geospatial analysis for everyone. Remote Sens Environ 202:18-27. https://doi.org/10.1016/j.rse.2017.06.031

15. Huffman GJ, Stocker EF, Bolvin DT, Nelkin EJ, Jackson T: GPM IMERG Final Precipitation L3 1 day 0.1 degree x 0.1 degree V06, in: Goddard Earth Sciences Data and Information Services Center (GES DISC), edited by: Andrey Savtchenko, Greenbelt, MD,

https://doi.org/10.5067/GPM/IMERGDF/DAY/06, 2019

16. Humanity Road: Cyclone Fani Situation Report 1, https://reliefweb.int/sites/reliefweb.int/files/resources/India\%20Cyclone\%20Fani\%202019.pdf, 2019

17. Indian Red Cross (IRC): Odisha FANI cyclone Assessment Report, https://www.indianredcross.org/notices/OdishaFaniAsessmentReport.pdf, 2019

18. Khalil GM (1993) The catastrophic cyclone of April 1991: Its Impact on the economy of Bangladesh. Nat Hazards 8(3):263-281. https://doi.org/10.1007/BF00690911

19. Kumar S, Lal P, Kumar A (2020) Turbulence of tropical cyclone 'Fani' in the Bay of Bengal and Indian subcontinent. Nat Hazards 103:1613-1622. https://doi.org/10.1007/s11069-020-04033-5

20. Kussul N, Shelestov A, Skakun S: Flood Monitoring from SAR Data, in: NATO Science for Peace and Security Series C: Environmental Security, edited by: Kogan, F., Powell, A., and Fedorov, O., Springer, Dordrecht, 19-29, https://doi.org/10.1007/978-90-481-9618-0_3, 2011

21. Li K, Li GS (2013) Risk assessment on storm surges in the coastal area of Guangdong Province. Nat Hazards 68:1129-1139. https://doi.org/10.1007/s11069-013-0682-2

Page 9/17 
22. Liu B, Zhu C (2020) Boosting effect of tropical cyclone "Fani" on the onset of the South China Sea summer monsoon in 2019. J Geophys Res Atmos 125:4. https://doi.org/10.1029/2019jd031891

23. Mohanty S, Nadimpalli R, Mohanty UC, Mohapatra M, Sharma A, Das AK, Sil S (2020a) Quasi-operational forecast guidance of extremely severe cyclonic storm Fani over the Bay of Bengal using high-resolution mesoscale models. Meteorol Atmos Phys. https://doi.org/10.1007/s00703-020-00751-4

24. Mohanty SK, Chatterjee R, Shaw R (2020b) Building Resilience of Critical Infrastructure: A Case of Impacts of Cyclones on the Power Sector in Odisha. Climate 8(6):73. https://doi.org/10.3390/cli8060073

25. Mohapatra M, Mandal GS, Bandyopadhyay BK, Tyagi A, Mohanty UC (2012) Classification of cyclone hazard prone districts of India. Nat Hazards 63:3:1601-1620. https://doi.org/10.1007/s11069-011-9891-8

26. Mohapatra M (2015) Cyclone hazard proneness of districts of India. J Earth Syst Sci 124(3):515-526. https://doi.org/10.1007/s12040-015-0556-y

27. Mohapatra M, Srivastava AK, Balachandran S, Geetha B: Inter-annual Variation and Trends in Tropical Cyclones and Monsoon Depressions over the North Indian Ocean, in: Observed Climate Variability and Change over the Indian Region, edited by: Rajeevan, M., and Nayak, S., Springer, Singapore, 89-106, https://doi.org/10.1007/978-981-10-2531-0_6, 2017

28. Mooley, D. A.: Severe cyclonic storms in the Bay of Bengal, 1877-1977. Mon. Wea. Rev., 108, 1647-1655, https://doi.org/10.1175/15200493(1980)108<1647:SCSITB>2.0.CO;2, 1980.

29. Mori N, Takemi T (2016) Impact assessment of coastal hazards due to future changes of tropical cyclones in the North Pacific Ocean, Weather Clim. Extremes 11:53-69. https://doi.org/10.1016/j.wace.2015.09.002

30. National Cyclone Risk Mitigation Project (NCRMP), Govt. of India, Cyclones \& their Impact in India: https://ncrmp.gov.in/cyclones-their-impact-in-india/, 2019, last access: 24 June 2020

31. Odisha State Disaster Management Authority (OSDMA), India UN, World Bank, \& Asian Development Bank (ADB): Cyclone Fani - Damage, Loss, and Assessment N, https://www.osdma.org/publication/cyclone-fani-2019-dlna-report/\#gsc.tab=0, 2019

32. Rao AD, Chittibabu P, Murty TS, Dube SK, Mohanty UC (2006) Vulnerability from storm surges and cyclone wind fields on the coast of Andhra Pradesh, India. Nat Hazards 41(3):515-529. https://doi.org/10.1007/s11069-006-9047-4

33. Regional Specialized Meteorological Centre (RSMC), Best Tracks Data IMD (1982-2020) http://www.rsmcnewdelhi.imd.gov.in/index.php? option=com_content\&view=article\&id=48\&ltemid=194\&lang=en, 2020, last access: 4 August 2020

34. Regional Specialized Meteorological Centre (RSMC), IMD, Cyclone Hazard Proneness of Districts of India: http://www.rsmcnewdelhi.imd.gov.in/images/pdf/climatalogy/frequency-cyclone/hazard.pdf, 2018a, last access: 26 June 2020

35. Regional Specialized Meteorological Centre (RSMC), IMD, Frequency of Formation of Cyclone: http://\&view=article\&id=55\&ltemid=203\&lang=en, 2019, last access: 30 April 2020

36. Singh OP, Ali Khan T, Rahman M (2000) Changes in the frequency of tropical cyclones over the North Indian Ocean, Meteorol. Atmos Phys 75:11-20. https://doi.org/10.1007/s007030070011

37. Singh OP, Khan TMA, Rahman S (2001) Has the frequency of intense tropical cyclones increased in the North. Indian Ocean? Curr Sci 80:575-580

38. Singh OP (2007) Long-term trends in the frequency of severe cyclones of Bay of Bengal: observations and simulations. Mausam 58:59-66

39. Srivastava AK, Ray S, De KC, U. S.: Trends in the frequency of cyclonic disturbances and their intensification over Indian Seas, Mausam, 51, 113-118, 2000

40. Uddin K, Matin MA, Meyer FJ (2019) Operational Flood Mapping Using Multi-Temporal Sentinel-1 SAR Images: A Case Study from Bangladesh. Remote Sens 11:13, 1581. https://doi.org/10.3390/rs11131581

41. UNICEF: India - Cyclone Fani Situation Report \# 2 (national), https://reliefweb.int/report/india/unicef-india-cyclone-fani-situation-report-2-national, 2019

42. United Nations (2019) World Population Prospects 2019: Highlights, Department of Economic and Social Affairs. Population Division, New York, 14 pp

43. Wang F, Xu YJ (2008) Hurricane Katrina-induced forest damage in relation to ecological factors at landscape scale. Environ Monit Assess $156: 1-4$. https://doi.org/10.1007/s10661-008-0500-6 491-507

44. Ward PJ, Marfai MA, Yulianto F, Hizbaron DR, Aerts JCJH (2011) Coastal inundation and damage exposure estimation: a case study for Jakarta. Nat Hazards 56:899-916. https://doi.org/10.1007/s11069-010-9599-1

45. World Meteorological Organization (WMO), Tropical Cyclones: https://public.wmo.int/en/our-mandate/focus-areas/natural-hazards-and-disaster-riskreduction/tropical-cyclones, 2020, last access: 2 August 2020

\section{Figures}



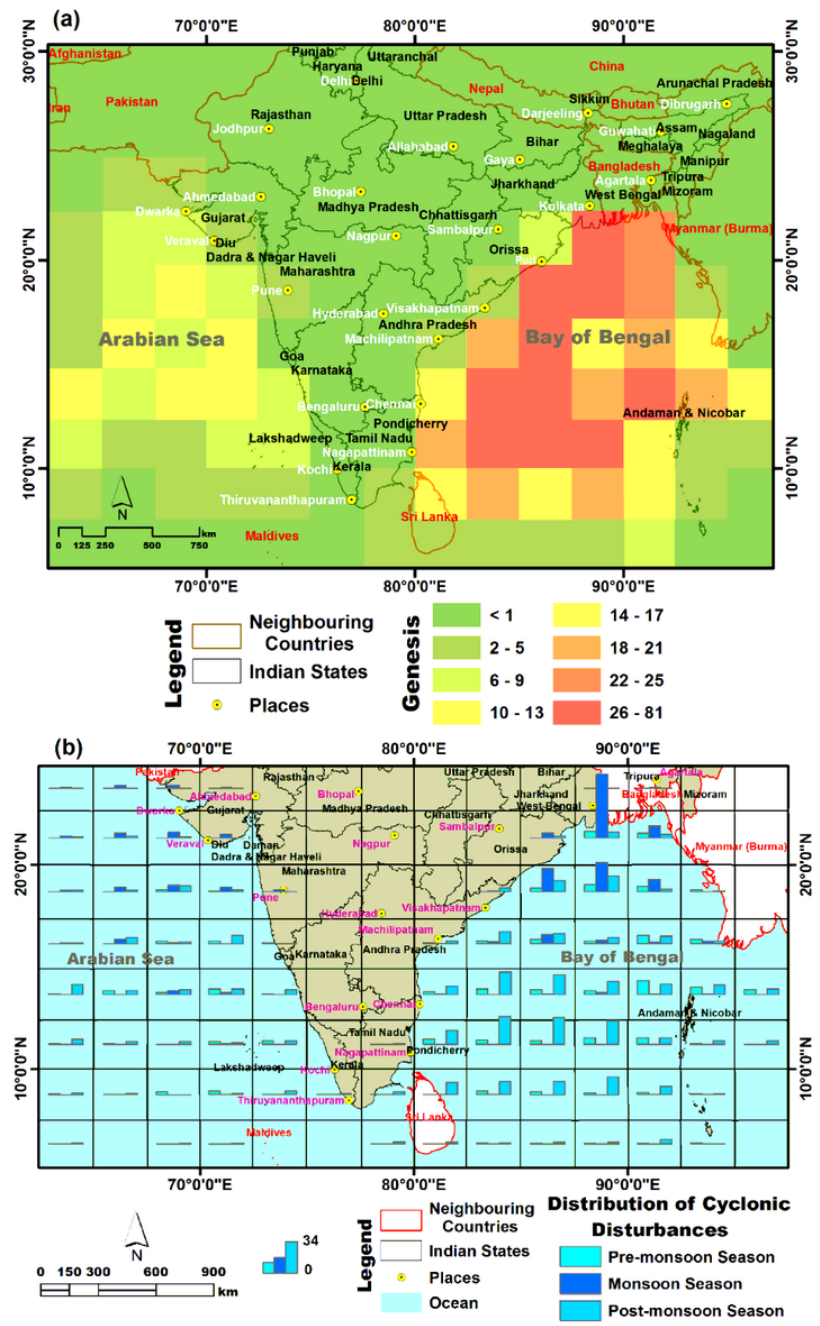

\section{Figure 1}

(a) Map showing the genesis of cyclonic disturbances (CS and above) over the North Indian Ocean (NIO) from 1891 to 2018 by dividing the entire region into $2^{\circ} 30 \bigotimes \times 2^{\circ} 30 \rrbracket$ grid based on India Meteorological Department (IMD) data source. (b) Seasonal (Pre-monsoon, Monsoon and Post-monsoon) distribution of cyclonic storms over the Arabian Sea and Bay of Bengal at the same time frame (1891-2018). The grid-wise data of NIO have been collected from the ${ }^{\circ}$ Regional Specialized Meteorological Centre (RSMC) for Tropical Cyclones over North Indian Ocean, India Meteorological Department (IMD) 
(a)

$\square$ Total CS and above over BoB $\square$ Total CS and above over AS

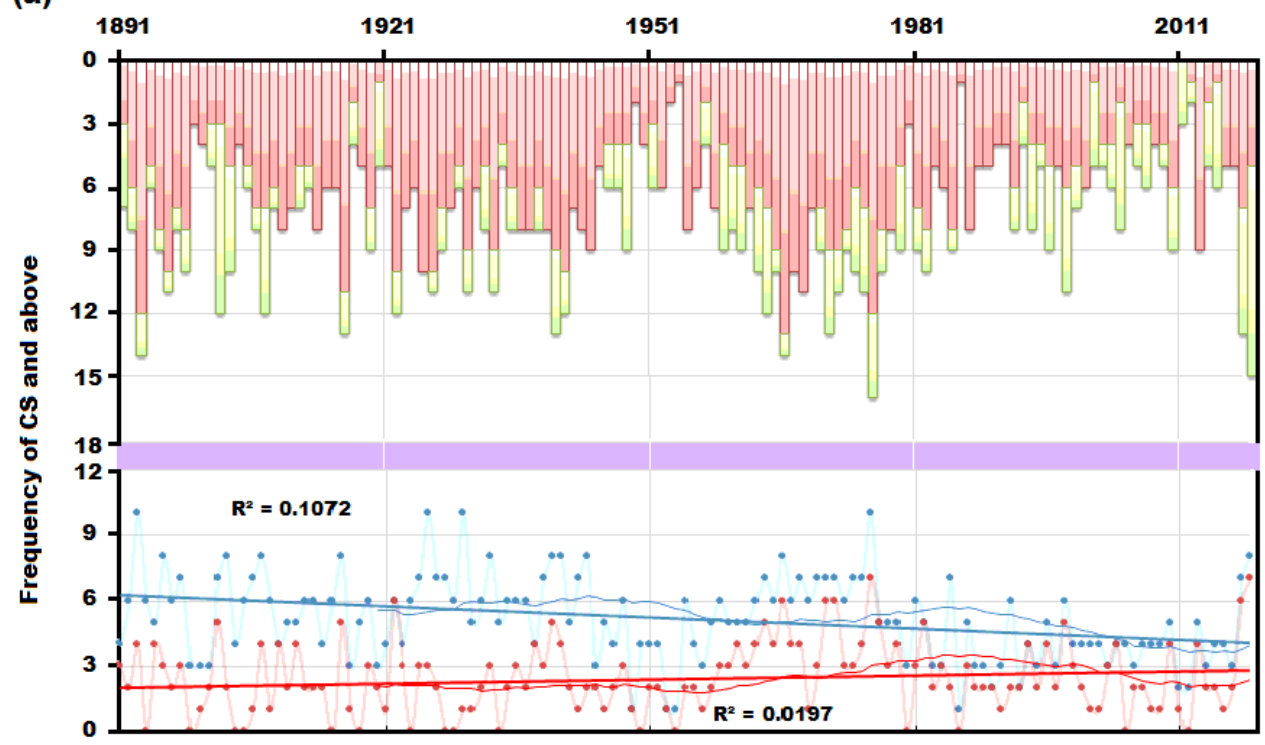

- Frequency of CS and above

- Frequency of SCS and above

30 per. Mov. Avg. (Frequency of CS and above)

- Poly. (Frequency of CS and above)

30 per. Mov. Avg. (Frequency of SCS and above)

Poly. (Frequency of Scs and above)

(b)

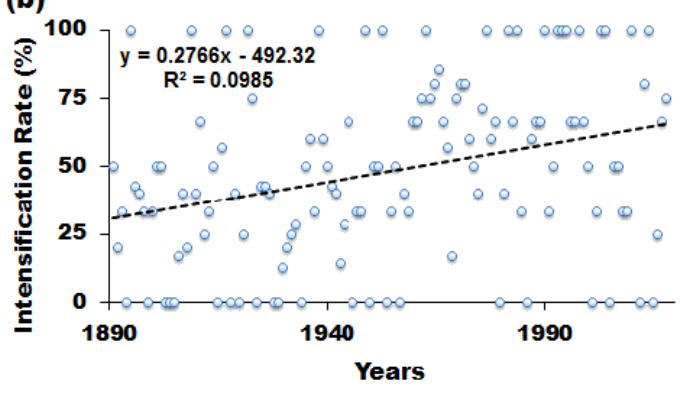

(c)

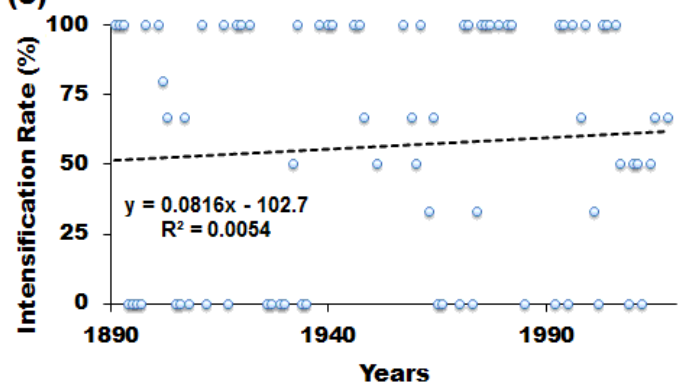

\section{Figure 2}

(a) Spatio-temporal distribution and trend analysis of tropical cyclones over the Bay of Bengal (BoB) and Arabian Sea (AS) for understanding the intensification rate of cyclonic storms to severe or more intensed cyclonic storms over: (b) BoB and (c) AS 


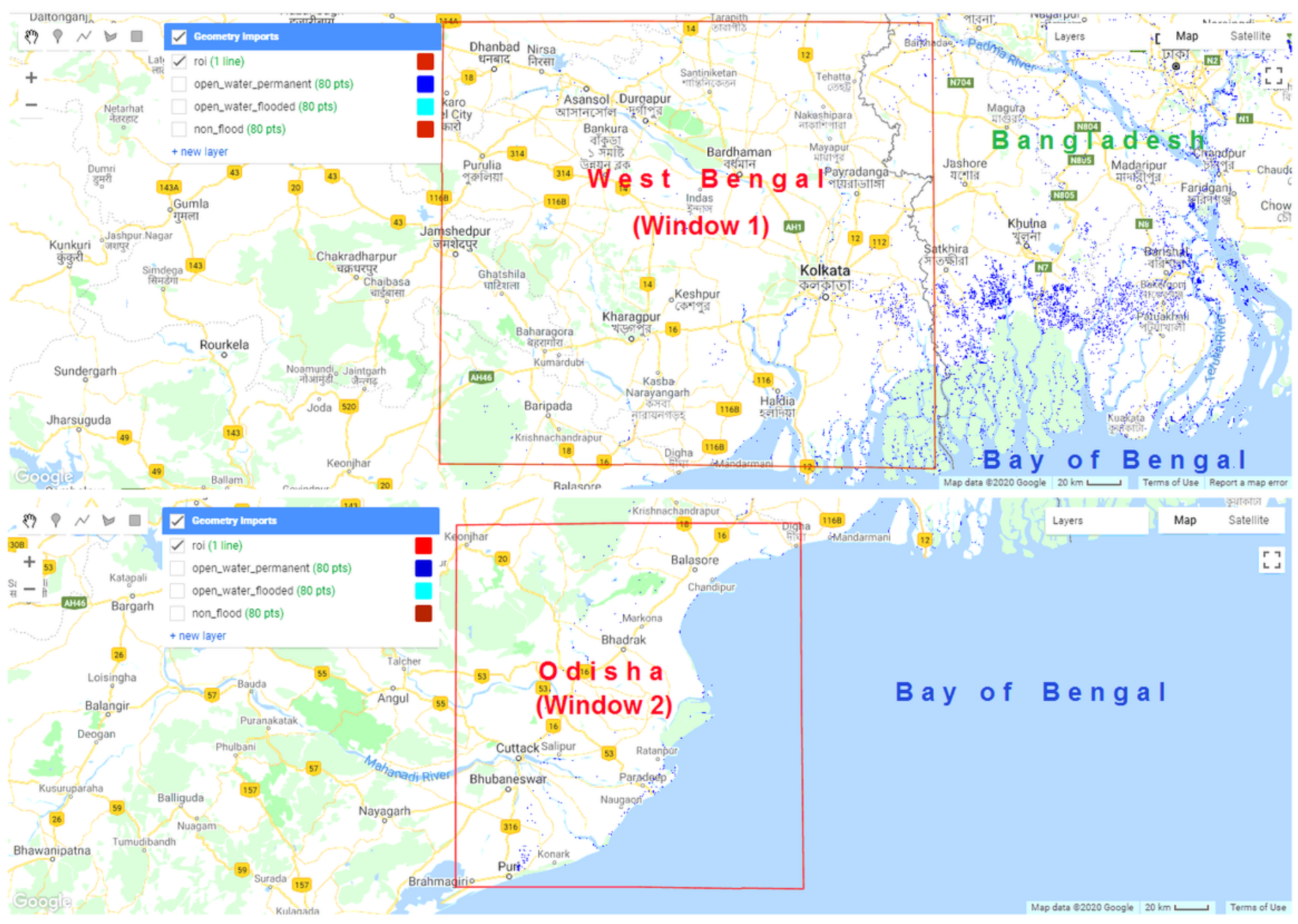

\section{Figure 3}

Two windows as region of interest (roi) for extracting major inundated regions over West Bengal and Odisha during ESCS Fani by analyzing the Sentinel-1 SAR GRD data in (c) Google Earth Engine (GEE) environment 


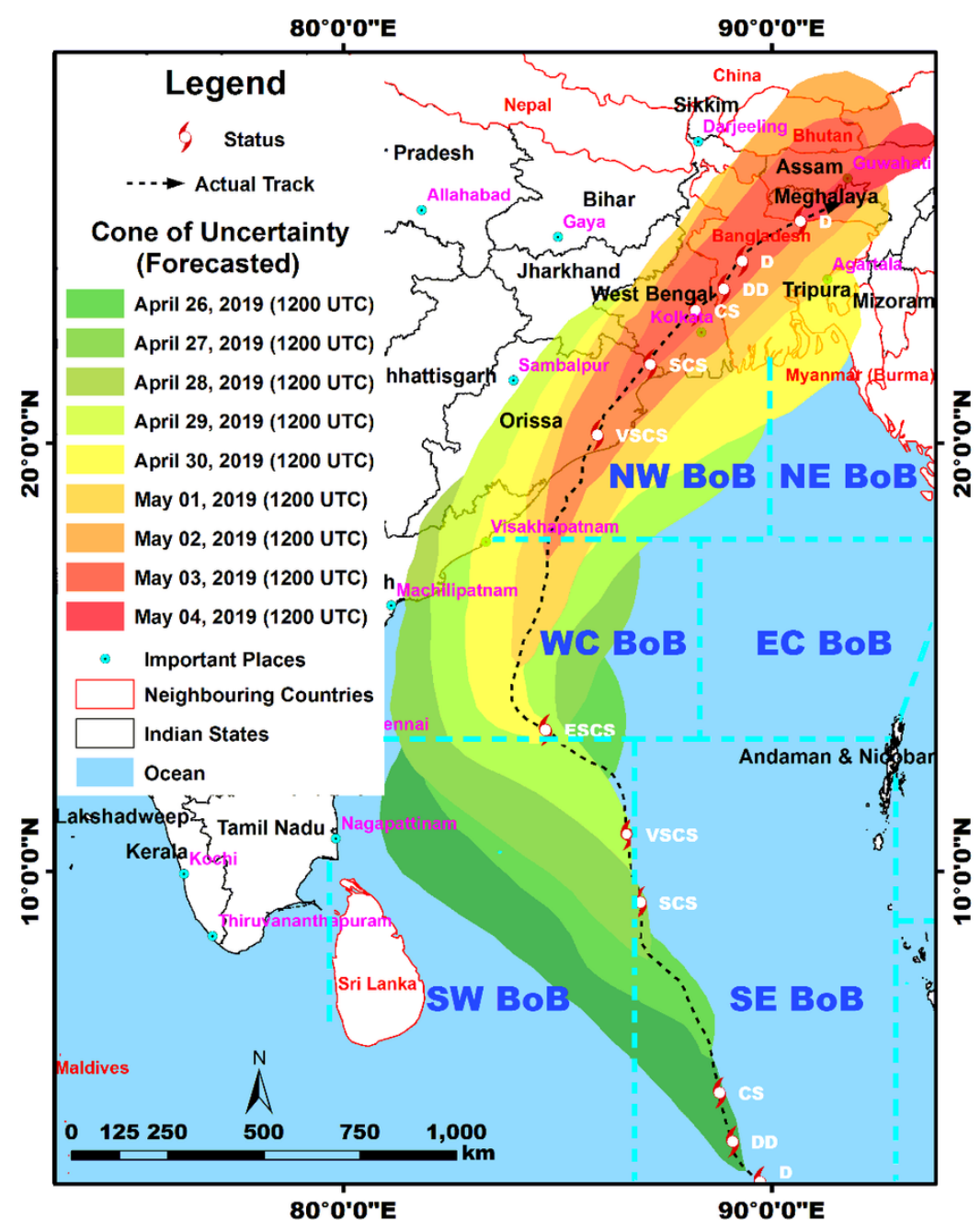

Figure 4

Advancement of ESCS Fani over time (26 April to 04 May 2019) has been shown with forecasted Cone of Uncertainty and storm status, such as Depression (D), Deep Depression (DD), Cyclonic Storm (CS), Severe Cyclonic Storm (SCS), Very Severe Cyclonic Storm (VSCS) and Extremely Severe Cyclonic Storm (ESCS) from the report of @ Regional Specialized Meteorological Centre (RSMC) for Tropical Cyclones over North Indian Ocean, India Meteorological Department (IMD). The Generic names like tropical cyclone or cyclonic storm is used to represent CS, SCS, VSCS and ESCS as a whole

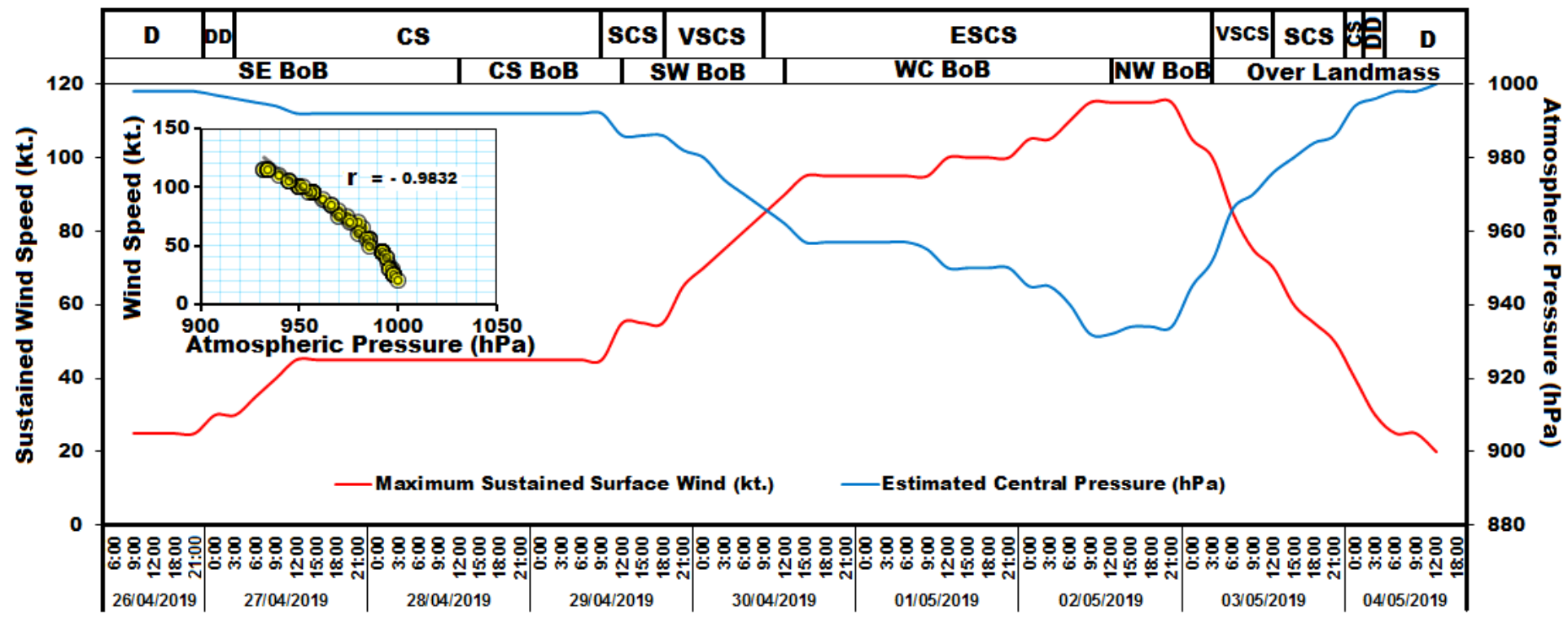

Figure 5 
Relationship between maximum sustained surface wind and estimated central pressure along the best track of cyclonic storm Fani with detailed status (CS, SCS, VSCS and ESCS) and track location

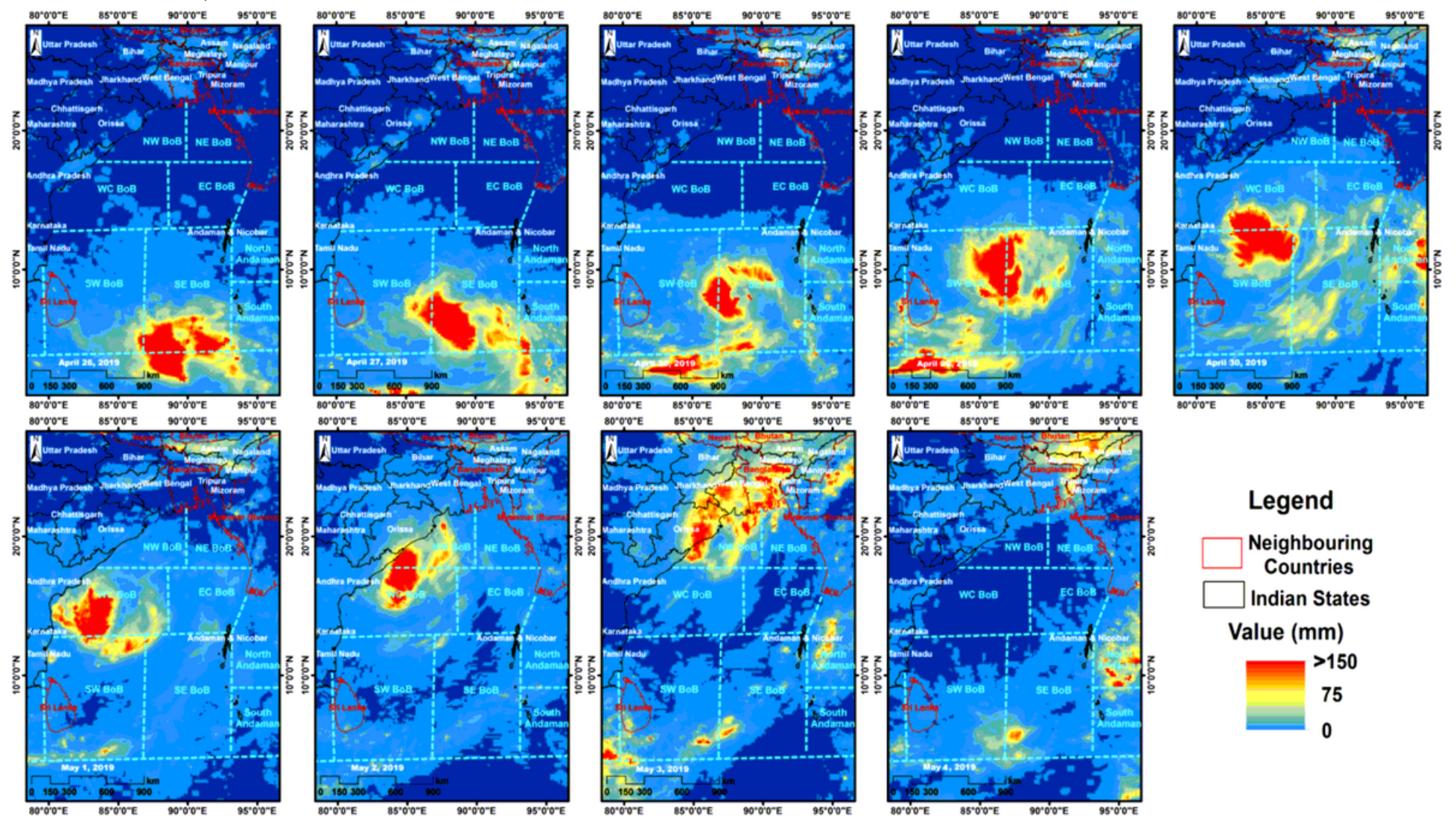

Figure 6

Distribution of rainfall over the Bay of Bengal and its adjacent Indian subcontinent, using NASA's GPM IMERG Final images 


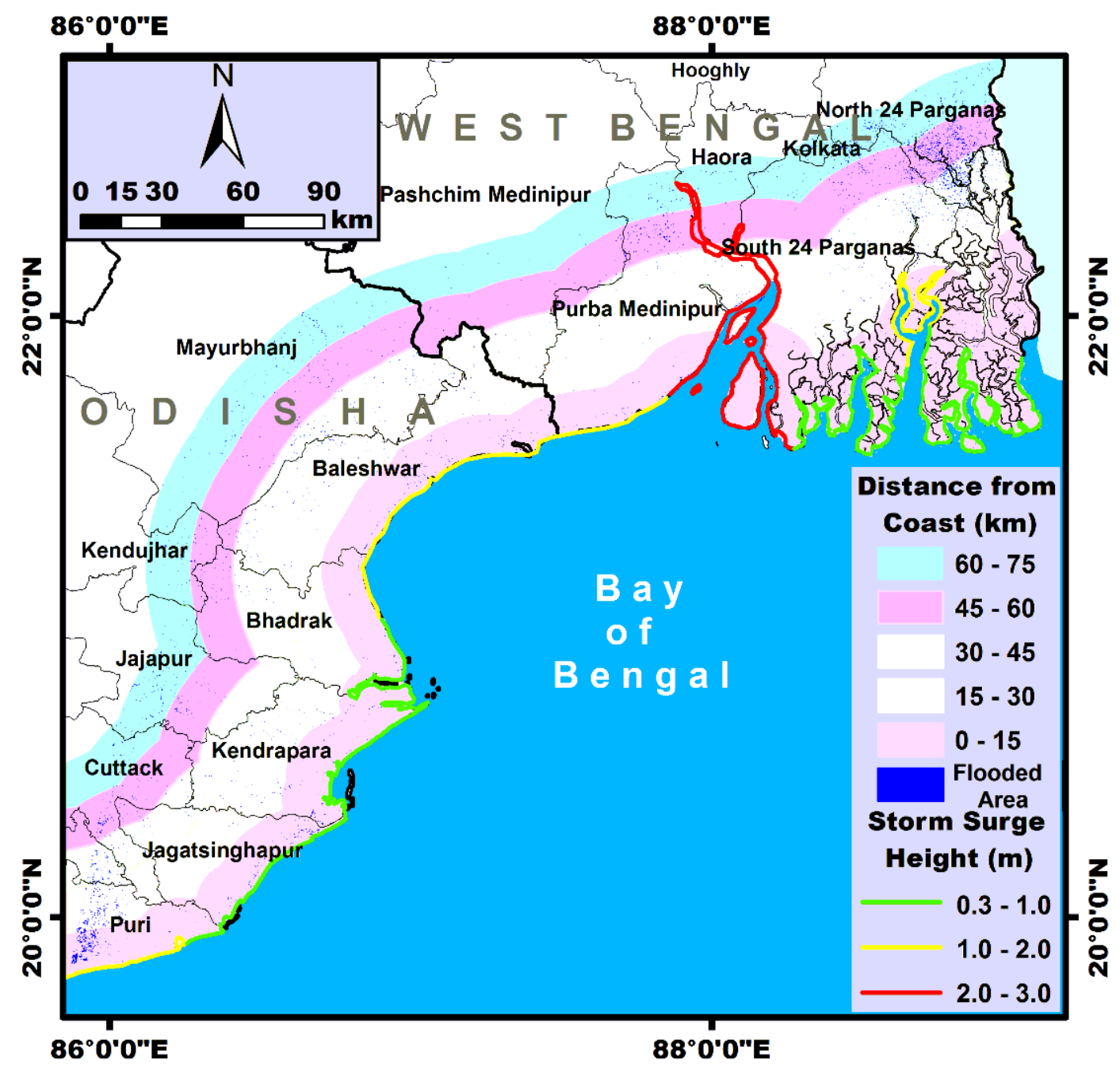

Figure 7

Flood map of West Bengal and Odisha (based on distance from the coast) with storm surge height (metres above sea level) information from @ Emergency Response Coordination Centre (ERCC) during ESCS Fani 

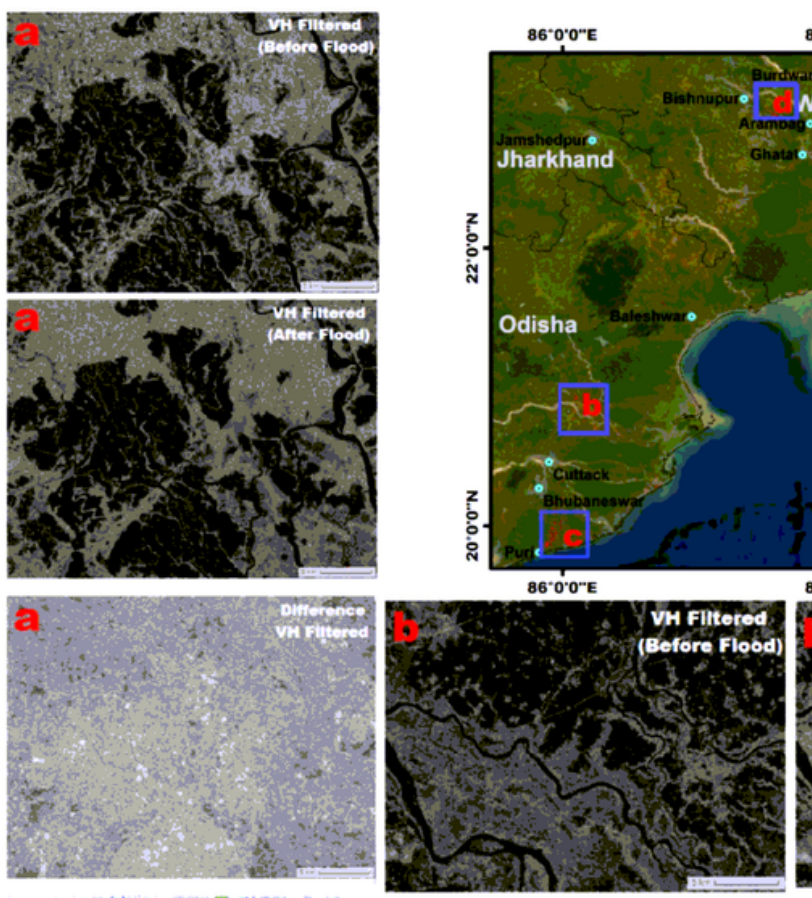

88.0"0"E
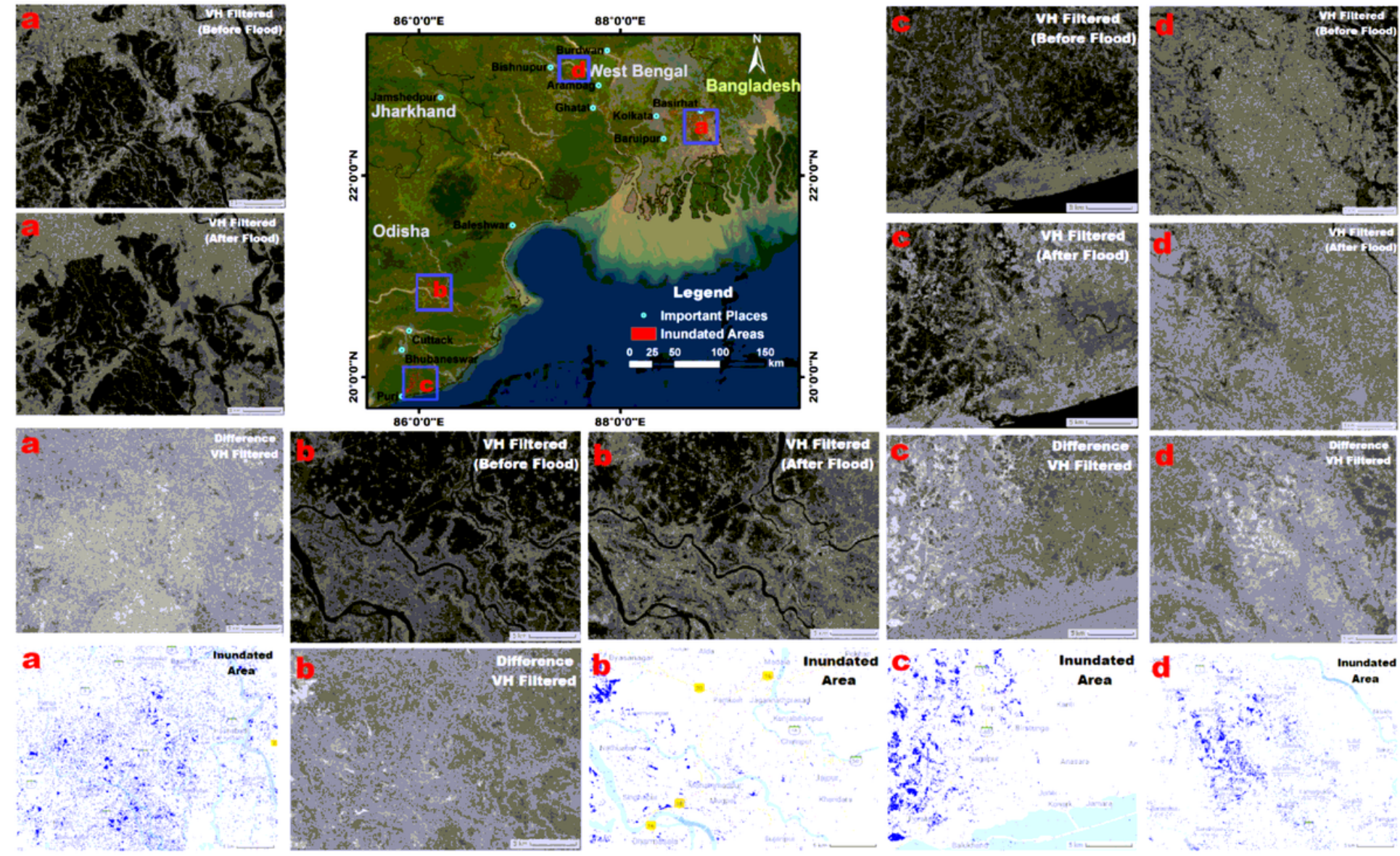

Figure 8

Flood map of West Bengal and Odisha (based on distance from the coast) with storm surge height (metres above sea level) information from @ Emergency Response Coordination Centre (ERCC) during ESCS Fani 